$$
\text { Chapter Irwenty-Nine }
$$

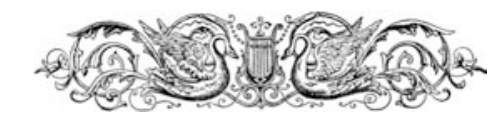

\title{
WHITMAN WRITINGS \\ SOLD: LECTURE ON LINCOLN BRINGS \$25 AT BRAM STOKER LIBRARY SALE (1913)
}

\section{Special Cable to The New York Times}

LONDON, July 7-At the sale at Sotheby's to-day of the Bram Stoker library, a collection oif [sic] fragments of Walt Whitman's writings was sold for \$82.50. Whitman's lecture on Abraham Lincoln was sold for $\$ 25$, and a letter from Whitman to Stoker for the same price.

Eleven volumes of the works of James Whitcomb Riley, with autograph inscriptions and a letter, brought $\$ 230$. 